\title{
The objects of his devotion
}

\author{
By Jeff Selth
}

Librarian Emeritus

University of California, Riverside

\section{The tale of a twisted bibliophile and the loss of 15,000 books.}

\section{$\mathrm{T}$} he conviction in January of Stephen Blumberg on the charge of stealing 21,000 books from a number of academic libraries, brings to mind a 12-year-old crime which almost equaled the present one in some of its statistics, and surpassed it in bizarreness. A narrative of its events might still be instructive in some very practical ways to keepers of books both rare and otherwise.

\section{The beginning}

Everyone in the library knew Mr. Cheshire by sight. Everyone was greeted each working day by his nod and embarrassed smile as he passed by briskly each day, recognizable to any newcomer by an immaculately starched white shirt, straightened black tie, pressed pearl-gray suit, polished black shoes, black brief-case, and a round, owl-like face. These were his insignia, along with his surname. Sumame only for although every other personality on campus, popular or otherwise, was known by a

\section{The best of our painting repro- ductions... now began to be removed with a skillfully handled blade.}

given name, Mr. Cheshire was always Mr. Cheshire, and only those with access to his personal file could have guessed at any other appellations.

It was reported that he had lived with his octogenarian mother all four decades of his life, frequently charming her with his virtuosity at the piano. He had begun his tertiary studies 20 years before, and passed slowly through the degrees: an A.B. first, then graduate work in French and comparative literature, ending with a dissertation on Charles Millevoye (1782-1816), a poet unknown to all but the hardiest of Francophiles. Unlike many of his fellow students, his reading was always done in the original languages, for Mr. Cheshire was fluent in most of the major European tongues, living and dead. In short, a model student and a scholar of great promise.

But also, apparently, a perennial student. ln the most extended conversation I was ever to have with him-it lasted two minutes - he blushed on admitting that his recent $\mathrm{Ph} . \mathrm{D}$., together with faculty accolades, had not procured him a job. Teaching positions were hard to find, but as five years went by with no sign that he could do better than one class a week teaching ESL for University Extension, one was led to wonder at his commitment to finding a position at all. Apparentlythe library was his Heaven, the classroom his Purgatory.

With a little thought I might have guessed that the topic with which to draw Mr. Cheshire into conversation was the one that for years had aroused the greatest ire among my colleagues. On at least three occasions, separated from each other by many years, large segments of the library's collection had been removed by thieves. First it was German literature; twice a set of Goethe's collected works (the Hamburg edition) was stolen in its entirety within a few months, 14 volumes each time. That thief finally went on to other things-no doubt other libraries-but later we found a string of French books to be missing, including 26 of the 30 
volumes of the new George Sand collection within a month or two of processing.

Then that criminal too left us, and a respite from theft was in store, but at a price we could not afford. The best of our painting reproductions - the culprit knew his art-now began to be removed with a skillfully handled blade. The mutilations escalated: an average of two books (several plates removed from each) were found by circulation assistants every day. Security was tightened; some of us played the game of guessing which books might be the next targets as the slasher worked his way through the history of art. Finally, with the approval of the art history faculty, all the volumes on painting were removed from the open stacks and locked up, unavailable to all students until a cage, approved and funded by the chancellor, could be constructed to house them under constant guard.

Perhaps the subconscious reason I did not speak of these things to Mr. Cheshire was the distress he must have felt merely to think of the maltreatment of these objects of his devotion. Now I will never know. For one day a man was seen cutting into an art book at the local public library, was visited by detectives, and after two long sessions of questioning finally confessed, and led police to what was left of more than 15,000 stolen volumes: French, German, and Latin literature, richly illustrated works of art (and loose plates), and piano scores.

And the legend under the suspect's photograph, in the next day's newspaper, read: "Gervase Donald Cheshire, aged 51."

\section{The capture}

The university library had not been the only one haunted by Mr. Cheshire. He had become as familiar a figure to the staff of the two nearest public libraries. The former had a treasure coveted by Cheshire: Polish Peasant Costumes, a portfolio of hand-painted pictures valued at $\$ 500$. One day he tried to borrow it, to be told it was noncirculating.

Acting no doubt on the principle that the left hand may not know what the right is doing, he dropped into a small suburban branch of the same library and asked if he might borrow the portfolio for research. An obliging staff member secured it from the main branch and checked it out to him.

Not content with a brief loan, he reported to the police that someone had broken into his car and stolen the pictures. But the ruse turned out to be the first in 20 years to backfire. A police officer, telephoning the public library for information about the portfolio, was told that a man answering to Cheshire's description had been observed mutilating a book just a few days before. Mr. Cheshire was invited to drop by the station to answer a few questions.

Eventually he broke down - to a degree-and admitted that the pictures, far from being stolen from his car, were in fact safe at home. But the police, or so they later insisted, by now had their suspicions fully aroused. An attempt to steal art works worth $\$ 500$, a mutilation testified to (though the witness could not positively identify the culprit in a line-up), and the full knowledge by police of the recent epidemic of art mutilations at the university library - all this added up in their minds to an extended caper by one man, the one now before them.

So they applied the pressure and interrogated Mr. Cheshire for an hour and a half. But the suspect held firm and denied all but the false report to the police. They had no choice but to let him go.

Hewent, conferred with the one person to whom he could speak freely, and received some maternal advice. Hardly new in the annals of crime, it was short, terse, and to the point: Get rid of the evidence. As a result, the Cheshire's neighbors were entertained for many hours the following day by the

\section{Hardly new in the annals of crime [the advice] was short, terse, and to the point: Get rid of the evidence.}

comings and goings of a huge flatbed truck. Two employees kept loading it to the brim with mountains of books, hauled them off, and returned for more. At least three trips were made, two to the nearest county dump and one to that of the adjacent community.

The neighbors wondered, the workers wondered, nobody called the police. And to the police themselves, who were so certain they had found their man, it never occurred that the suspect might take fright and destroy the evidence. No thought to dispatch an officer just to watch the Cheshire house for a day or two. And so some 15,000 volumes, weighing 20,000 pounds, were carted off to the dumps that day, and within 30 minutes of arrival were ground under 10 or 20 feet of earth by the efficient bulldozers of two counties.

One final opportunity to salvage the treasure was lost to hesitation. A college student, depositing her tree trimmings at the dump, beheld the unusual sight of thousands of books, piled high, not 50 feet away. She walked over and examined some: all were scholarly books, in good condition, and she too wondered. But she kept her wonder to herself till her husband came home for the day, two or three hours later.

The husband proved a man of action. He reached for the phone and called the university library whose stamp appeared plainly on the two dozen 
books his wife had picked up as samples. A senior librarian took the call and within ten minutes was on the phone to the county dump; but the bulldozing had been completed hours before.

The librarian notified police early the following morning; promptly at 3:30 p.m. detectives arrived at the dump. They later questioned the Cheshire neighbors, who described the strange happenings of the previous day. At $6: 30$ in the evening the model student was arrested.

This time he really broke down, admitting taking books from the university library at an average rate of two a week for 20 years. (Math was clearly not his forté; since about two-thirds of the loot was from that one institution, it must have been close to ten a week.) Not one to discriminate against the less scholarly institutions, he had also taken freely from the two public libraries, and even from Europe. $\mathrm{He}$ also revealed that 18 months earlier he had shifted gears, removing plates from art books and conceal-

\section{There must have been some shelter within the library where he could work in peace and security, but where was it?}

ing them easilyin his briefcase when passing through the checkpoint where patrons were required to show what they were carrying out of the building. Most of the books were stacked (rather tightly, one would imagine) in his garage; but the plates, neatly excised, held a place of honor inside the house, and the music scores enlarged his piano repertoire.

The next day representatives of the victim libraries had a chance to see the remaining evidence They gathered in police headquarters for a briefing, then drove out to the scene of the most extensive dumping activity.

It was a hot day and the barren terrain offered no spot of shade. The bulldozer operator led us to the two locations where he had ground the books under. His memory was uncanny, for when he began his bulldozing - or de-bulldozing - it was but a few minutes before the earth yielded its grizzly harvest. Volumes were exhumed bearing the university library's stamp: books in German, French, Latin, Russian, Portuguese; lovely art books from the public libraries; one bearing the emblem of the University of Bordeaux. And a subject field never suspected earlier: a number of works on the glamour queens and vamps of the cinema, from Bara to Monroe.

I noticed that the university's books appeared to be date-stamped in the normal manner and a thought occurred to me. Had the last date in each book been stamped by a staff member, the loans would have been recorded in the circulation files and the books recalled when overdue. Certainly these thousands of volumes were not piled up in any overdue file in our Circulation Department. There was only one possibility: each last date must have been stamped by the thief himself. He had simply purchased an ordinary date stamp of the size used by the library, imprinted a plausible date on any book that took his fancy, and shown it to the staff as he passed the checkout desk. The obviousness of the ruse had occurred to nobody until a new circulation head introduced a stamp which added a code before the date, one not readily available in the stationery stores.

(There was another obvious ruse, the thought of which might have led quickly to the culprit's apprehension and averted the massacre. No slasher could have been at the same time so prolific and so meticulously accurate while hunched up between rows of stacks, with one eye constantly cocked to avoid detection. There must have been some shelter within the library where he could work in peace and security, but where was it? Perhaps only in one of the 75 carrels and Cheshire, as a long-time postgraduate student, had been assigned one of them for many years.)

The books recovered, less than $10 \%$ of those dumped, were of little use to their owners. They were carefully stowed in sacks, but for evidence rather than restoration. (As the university library's head of special collections wrote in the next issue of our quarterly journal: "A search of the literature on conservation and preservation of library materials fails to reveal any cases of restoration of books twisted and torn by the cleats on bulldozer tracks.") Perhaps one in ten was salvageable, and not to their once pristine condition. To every library employee the name of Gervais Donald Chesshir (to transmit the spelling from the title page of his dissertation) was mud.

\section{The trial}

The defendant's first court appearance brought two surprises. One was that Mr. Cheshire pleaded not guilty, the other that his mother was charged with knowing about the thefts and shielding her son from arrest. (The local newspaper's account offered a third: it gave the man's age as 51 and his mother's as 65. .)

The libraries were permitted a month to list and appraise the books recovered, and estimate the replacement cost of the total destroyed. The latter task was easy, given the dump's weight receipts; the former was Herculean, since each of the thousand books disinterred had to be located in a publication suggesting a value, and every one of the plates had to be matched with the book from which it had been 
removed. The university library requested a deferral of the arraignment.

The next deferral was requested by the district attorney, who claimed to need more time to prepare his case. The third came from the judge, as the scheduled date coincided with his vacation. And the fourth came when the judge, back from vacation, took a look at the case and disqualified himself; he was an alumnus of the university and a supporter of its library.

When the hearing finally came to pass it was an anti-climax, since Cheshire changed his plea and entered nolo contendere. A court psychiatrist testified to his "irresistible impulse repeated compulsively many thousands of times over twenty years," opined that he was legally insane and not responsible for his actions under criminal definitions, and recommended against imprisonment. The verdict (on Cheshire only, Mama seemed to have been forgotten) was five years probation, repayment to the university library of $\$ 6,000$ - a token of the estimated $\$ 400,000$ replacement cost-over five years, psychiatric or psychological treatment, and a ban on patronage of any library.

The last element was the hardest to enforce. No doubt the three local libraries would not see $\mathrm{Mr}$.
Cheshire for several years, but what about the others? Within half an hour by car were another dozen public libraries and an equal number of the academic variety. The question among librarians was not whether Mr. Cheshire would show up again, but when and where.

Or could the problem be solved by a mug shot, printed in the hundreds and distributed to every library within a radius of . .. 50 miles? 100 ? 500 ? The entire North American continent? And the University of Bordeaux?

\section{Afterword}

In the 12 years since Cheshire was caught with the goods and sentenced by the court, he has not been heard from much. I do know that he diligently paid the $\$ 6,000$ he was ordered to pay, and did it in four-and-a-half years instead of the five required. Of that $\$ 6,000$, half went to the university library and half to the public library from which he stole. He has been seen once that I know of-in the public library he had victimized for so long, after the five-year probation period ordered by the judge. A librarian there recognized Cheshire and asked him to leave. He did.

\section{Futurist to speak at ACRL Sixth National Conference}

Paul Saffo, a research fellow at the Institute for the Future, will speak at the ACRL Sixth National Conference in Salt Lake City. His talk, "The Electronic Piñata; Information Technologies and the Future of the Library," is scheduled for April 12, 1992.

"We live in a moment between two revolutions, one of print, not quite spent, and another of electronics not quite underway. This collision will take decades to sort out, but its impact on libraries will be immediate and profound," Saffo stated. "My talk will set these changes in a historical context, and identify the surprises to come, exploning the implications for libraries and their users."

A specialist in the long-term commercial and policy impacts of new information technologies, Saffo devotes much of his time to issues affecting publishers and libraries. Saffo is a contributing editor for Infoworld Magazine, and writes a column for the Los Angeles

Times. He also is a member of the editorial board of the Journal of Computers and Society. He holds a B.A. from Harvard College, an LL.B from Cambridge University, and a J.D. from Stanford Law School. At Stanford he was editor-in-chief of the Stanford Joumal of International Law. He is also a Fellow of the Cambridge Philosophical Society, an academic society affiliated with Cambridge University.

The Institute for the Future is a 21-year-old management consulting foundation that provides long-range planning and forecasting services to Fortune 100 companies and government agencies.

Preliminary program and registration materials for the Sixth National Conference are now available. Advance registration is $\$ 135$ for ACRL members and $\$ 255$ for non-members. Addi-

Futurist Paul Saffo will speak on changing technologies at the ACRL Conference. tional information is available from the ACRL office. Phone (800) 545-2433, ext. 2516. 